http://www.jfas.info

\title{
ATMOSPHERIC WATER HARVESTER: METEOROLOGICAL EFFECT ON WATER COLLECTION
}

\author{
N. A. Zol ${ }^{1}$, N. H.M. Isa ${ }^{1}$, N. R. Awang ${ }^{1}$, M. I. Ahmad ${ }^{2}$, M. S. M. Rasat ${ }^{2}$, M. F. M. Amin ${ }^{1, *}$ and \\ Z. I. Rizman ${ }^{3}$ \\ ${ }^{1}$ Faculty of Earth Science, Universiti Malaysia Kelantan, Jeli, Kelantan, Malaysia \\ ${ }^{2}$ Faculty of Bio-Engineering and Technology, Universiti Malaysia Kelantan, Jeli, Kelantan, \\ Malaysia \\ ${ }^{3}$ Faculty of Electrical Engineering, UniversitiTeknologi MARA, 23000 Dungun, Terengganu, \\ Malaysia
}

Published online: 10 September 2017

\begin{abstract}
Cylindrical shape of atmospheric water harvester model was developed, which located at Universiti Malaysia Kelantan. The materials used for the mesh, fins, core and the frame structure are stainless steel which were light and strong to withstand the elements. The experiment was carried out on February and March 2017. Primary data collection on volume of water was collected from daily monitoring. Secondary data collection was obtained from meteorological data, which contains the data of wind speed, wind direction, dry bulb temperature, relative humidity and rainfall.Descriptive analysis was used to relate the volume of water collection with the meteorological data. It shown the suitability of cylindrical shape of atmospheric water harvester model to be used in harvesting atmospheric water. Meteorological factors implements an important role in maximizing the volume of water collection.
\end{abstract}

Keywords: atmospheric water harvester; meteorological effect; water collection.

Author Correspondence, e-mail: mohamadfaiz@umk.edu.my

doi: http://dx.doi.org/10.4314/jfas.v9i3s.69 


\section{INTRODUCTION}

Of all the earth's resources, water is the most fundamental to life [10]. Every living organism needs water for survival. Normally, water is needed for a wide variety of purposes such as in industrial and agricultural sector. Although supplying water for people in tropical regions has gained high importance in the recent days [11], however, water resources in many parts of the world are pushed to their natural limits. This is due to the fact that increasing population has put tremendous pressure on the natural resources.

Currently, the issue of water scarcity has become one of major global concern [1]. Water scarcity can be defined as the lack of access to adequate quantities of water for human and environmental uses is increasingly being recognized in many countries as a serious and growing concern [2]. It affects every aspect of human life including health, agricultural yields, food security, technical development and the economy of states [8]. Actually, the water scarcity already affects every continent. Around 1.2 billion people or almost one-fifth of the world's population, live in areas of physical scarcity and 500 million people are approaching this situation. Another 1.6 billion people or almost one quarter of the world's population face economic water shortage [12].

Due to the pressing global challenge of water scarcity, the alternative methods of water collection have become increasingly popular in recent years. Alternative water sources are sustainable sources of water, not supplied from fresh surface water or groundwater that offset the demand for freshwater [3]. One such example is the idea of atmospheric water harvesting. In [13] stated that atmospheric water harvesting is an adaptation of natural processes of water cycles which involve condensation and precipitation.

So, in order to examine the potential water in the atmosphere, atmospheric water harvester model was developed since it is one of the sustainable alternative water resources [6]. Normally, the atmosphere contains water in the form of water vapor, moisture and so on. Within that amount, almost $35 \%$ of the water is wasted. This amount of water can be used with the help of an atmospheric water harvester. This research was conducted to develop prototype for a new design of atmospheric water harvester model and to investigate the influence of meteorological effect on the volume of water collection. 


\section{MATERIAL AND METHOD}

This research was conducted in Universiti Malaysia Kelantan Jeli Campus. It was located in elongated hill of Jeli district at Kelantan, Malaysia [7]. Normally, hilly areas in Jeli were distributed in the foot of mountain ranges, the backbone of Peninsular Malaysia. This landscape forms two types of hill included isolated and elongated hills. However, the elongated hills are ridges but usually lower than mountain ridges [5]. Therefore, the hilly areas can be also known as highland area because of its limited water access. Apart from that, Jeli district was a tropical rainforest climate where it received high annual amount of rain water [9].

Universiti Malaysia Kelantan Jeli Campus was lied between a longitude 101 52'04.57” East and latitude $5^{\circ} 44^{\prime} 46.50^{\prime \prime}$ North. Jeli was situated in western part of Kelantan, strategically located near Kelantan-Perak state border and Malaysia-Thailand international border. As of 2010, Jeli district has a population of 48,000 peoples [4]. It shows that the amount of population were quite large to compete with each other, in order to get enough basic needs especially water.

\subsection{Installation of Materials}

Based on previous research, there are various design and technique that have been carried out to harvest atmospheric water. Thus, in this research, the study on maximizing the volume of water collection has been continued through the creation of a new atmospheric water harvester design which is in cylindrical shape. The atmospheric water harvester was developed by using material that can lower down the dew temperature. The materials for the mesh, fins, core and the frame structure were selected based material which are light and strong to withstand the elements. The mesh materials used are stainless steel and aluminum mesh with 9.3-18.6 $\mathrm{m}^{2}$ surface area. $10 \mathrm{~L}$ of mineral water bottle was attached under the funnel of atmospheric water harvester to act as water collector. 


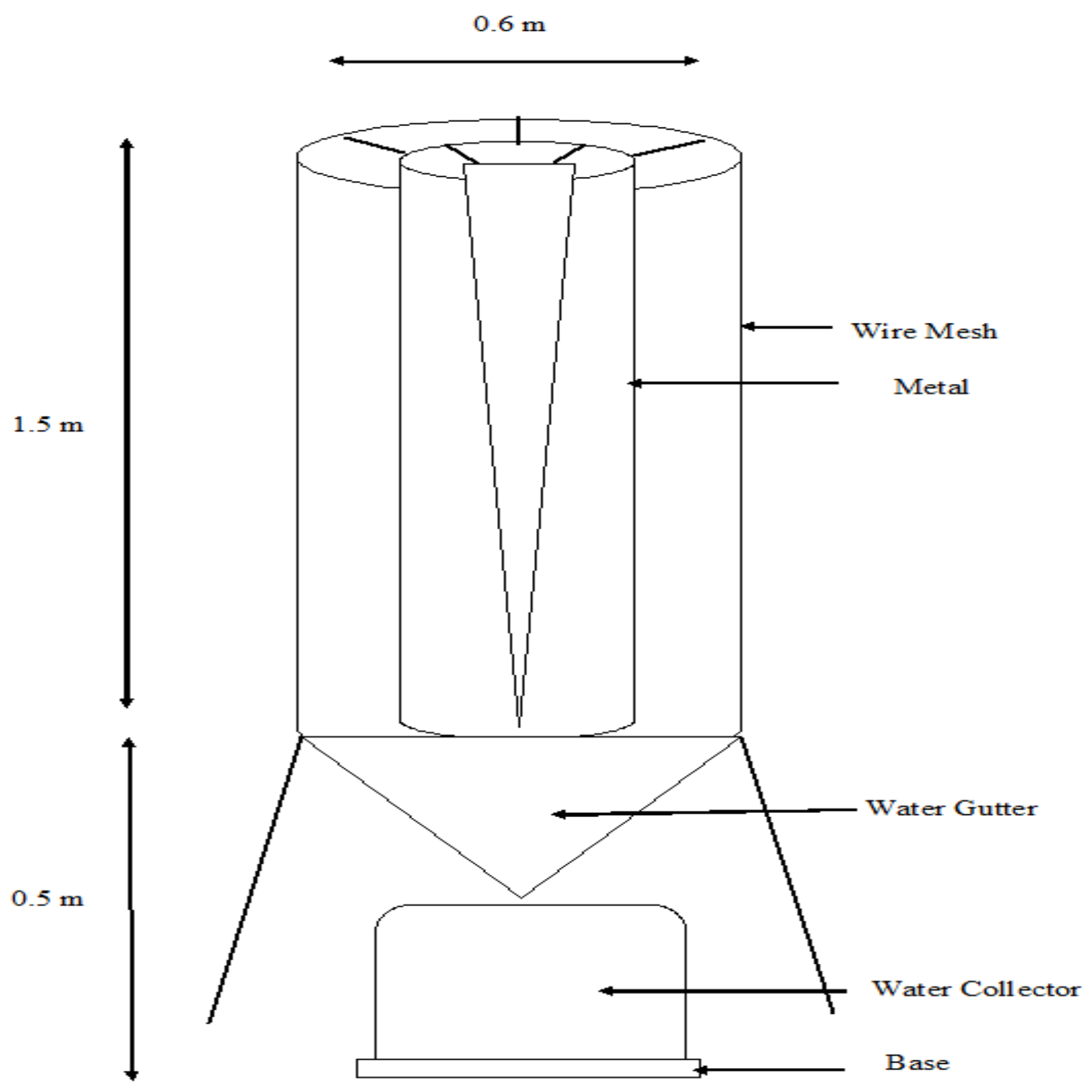

Fig.1.The prototype of atmospheric water harvester model

In Malaysia, this type of atmospheric water harvester model has not yet been tested scientifically. Hence, the perfect design that suitable and could harvest a high volume of water in Malaysia climate and humidity is relatively unknown. Therefore, in order to identify the most suitable design in catching atmospheric water like fog and rain, the efficiency of this prototype was tested in this research.

\subsection{Experimental Setup}

The experiment was carried out for two months continuously started from 1st of February 2017 until 31st of March 2017. Monitoring and collecting method have been used in this 
research. The data of water collection was observed between 7.30 a.m. to 8.00 a.m. everyday. It shows that the data was taken once every 24 hours period. Based on daily observation, the time from 7.30 a.m. to 8.00 a.m. was quite suitable to collect data. It is because after 8.00 a.m., the water collected was evaporated due to direct heat from the sunlight.

In this research, the meteorological data collection used included the data of wind speed, wind direction, dry bulb temperature, relative humidity and rainfall were derived from the nearest weather station situated at Masjid BesarJeli which owned by Malaysian Meteorological Department. It was located at longitude $101^{\circ} 50^{\prime} 45^{\prime \prime}$ East and latitude 5० 41' 39" North with the elevation of $93 \mathrm{~m}$.

\subsection{Statistical Analysis}

All analysis results were subjected to statistical methods to determine mean and standard deviation using the suitable statistical software which is known as Statistical Package for the Social Sciences (SPSS). Thus, to relate primary data collection which was the volume of water collection with secondary data collection including meteorological factor such as wind speed, wind direction, dry bulb temperature, relative humidity and rainfall, the descriptive analysis was used.

\section{RESULTS AND DISCUSSION}

\subsection{Descriptive Analysis on Volume of Water Collected (ml) on February and March} 2017

Table 1.Volume of water collected for cylindrical shape of atmospheric water harvester model

\begin{tabular}{cc}
\hline Months & Volume of Water Collected ( ml ) \\
\hline February 2017 & 17,968 \\
\hline March 2017 & 30,697 \\
\hline
\end{tabular}

Table 1 shows the volume of water collected for cylindrical shape of atmospheric water harvester model on February and March 2017. Based on Table 1, on February 2017, the total volume of water collected was 17,968 ml. While on March 2017, the total volume of water collected was $30,697 \mathrm{ml}$. This results shows that the volume of water collected on March 2017 is higher than the volume of water collected on February 2017. 
Table 2.Volume of water collected on February 2017

\begin{tabular}{|c|c|c|c|c|c|c|}
\hline $\begin{array}{c}\text { No. } \\
\text { (Days) }\end{array}$ & $\begin{array}{c}\text { Relative } \\
\text { Humidity } \\
\text { (\%) }\end{array}$ & $\begin{array}{c}\text { Wind } \\
\text { Direction } \\
\left(^{\circ}\right)\end{array}$ & $\begin{array}{l}\text { Wind } \\
\text { Speed } \\
(\mathrm{m} / \mathrm{s})\end{array}$ & $\begin{array}{c}\text { Rainfall } \\
\text { (mm) }\end{array}$ & $\begin{array}{c}\text { Dry Bulb } \\
\text { Temperature } \\
\left({ }^{\circ} \mathrm{C}\right)\end{array}$ & $\begin{array}{l}\text { Volume of } \\
\text { Water } \\
\text { Collected } \\
\text { (ml) }\end{array}$ \\
\hline 1 & 94 & 245 & 0.7 & 0.0 & 22.7 & 0 \\
\hline 2 & 90 & 165 & 0.6 & 0.0 & 22.7 & 0 \\
\hline 3 & 92 & 050 & 0.8 & 0.0 & 23.5 & 130 \\
\hline 4 & 95 & 270 & 0.6 & 0.0 & 23.7 & 170 \\
\hline 5 & 95 & 255 & 0.9 & 0.0 & 22.6 & 78 \\
\hline 6 & 94 & 250 & 1.5 & 0.0 & 23.5 & 52 \\
\hline 7 & 90 & 215 & 0.9 & 0.0 & 21.0 & 0 \\
\hline 8 & 92 & 270 & 0.9 & 0.0 & 22.3 & 0 \\
\hline 9 & 93 & 270 & 1.0 & 0.0 & 22.4 & 0 \\
\hline 10 & 92 & 225 & 0.8 & 0.0 & 22.5 & 940 \\
\hline 11 & 95 & 050 & 0.6 & 0.4 & 23.2 & 170 \\
\hline 12 & 96 & 055 & 0.5 & 0.0 & 22.5 & 0 \\
\hline 13 & 95 & 030 & 0.4 & 0.0 & 22.6 & 130 \\
\hline 14 & 96 & 360 & 0.4 & 0.0 & 22.2 & 380 \\
\hline 15 & 95 & 290 & 0.4 & 0.0 & 22.8 & 2160 \\
\hline 16 & 94 & 280 & 0.7 & 0.0 & 21.6 & 130 \\
\hline 17 & 95 & 300 & 0.5 & 0.0 & 22.4 & 26 \\
\hline 18 & 92 & 270 & 1.2 & 0.0 & 23.4 & 7300 \\
\hline 19 & 96 & 320 & 0.4 & 4.1 & 23.1 & 0 \\
\hline 20 & 96 & 170 & 0.3 & 0.0 & 21.8 & 0 \\
\hline 21 & 96 & 270 & 1.5 & 0.0 & 22.1 & 0 \\
\hline 22 & 95 & 230 & 0.5 & 0.0 & 22.4 & 0 \\
\hline 23 & 95 & 200 & 0.5 & 0.0 & 24.1 & 26 \\
\hline 24 & 96 & 270 & 0.6 & 0.0 & 22.8 & 26 \\
\hline
\end{tabular}




\begin{tabular}{rrrrrrr}
\hline 25 & 94 & 165 & 0.6 & 0.0 & 24.0 & 130 \\
26 & 96 & 290 & 0.5 & 0.0 & 23.2 & 1660 \\
27 & 96 & 030 & 0.5 & 0.0 & 23.7 & 1900 \\
28 & 97 & 035 & 0.5 & 0.0 & 22.8 & 2560 \\
& & & & & Sum $=17,968 \mathrm{ml}$ \\
\hline
\end{tabular}

Based on Table 2, there are 10 days on February 2017 has no record for volume of water collected which are on 1st, 2nd, 7th, 8th, 9th, 12th, 19th, 20th, 21st and 22ndof February where the weather is very hot. Both on 23rd and 24th of February contains the minimum volume of water collected with only $26 \mathrm{ml}$ because the water collection had been evaporated into the atmosphere. The volume of water collected on 18th of February shows the maximum amount of water collection with $7300 \mathrm{ml}$ due to continuous rainy day. The overall volume of water collected on February 2017 is $17,968 \mathrm{ml}$.

Table 3.Volume of water collected on March 2017

\begin{tabular}{|c|c|c|c|c|c|c|}
\hline $\begin{array}{c}\text { No. } \\
\text { (Days) }\end{array}$ & $\begin{array}{c}\text { Relative } \\
\text { Humidity } \\
\text { (\%) }\end{array}$ & $\begin{array}{c}\text { Wind } \\
\text { Direction } \\
\left(^{\circ}\right)\end{array}$ & $\begin{array}{r}\text { Wind } \\
\text { Speed } \\
(\mathrm{m} / \mathrm{s})\end{array}$ & $\begin{array}{c}\text { Rainfall } \\
\text { (mm) }\end{array}$ & $\begin{array}{c}\text { Dry Bulb } \\
\text { Temperature } \\
\left({ }^{\circ} \mathrm{C}\right)\end{array}$ & $\begin{array}{c}\text { Volume of } \\
\text { Water } \\
\text { Collected } \\
\text { (ml) }\end{array}$ \\
\hline 1 & 96 & 065 & 0.7 & 0.1 & 23.8 & 5580 \\
\hline 2 & 96 & 055 & 0.4 & 0.0 & 23.9 & 3180 \\
\hline 3 & 96 & 015 & 0.3 & 0.0 & 22.8 & 130 \\
\hline 4 & 96 & 150 & 0.5 & 0.0 & 22.4 & 26 \\
\hline 5 & 94 & 310 & 0.6 & 0.0 & 23.7 & 0 \\
\hline 6 & 94 & 270 & 0.5 & 0.0 & 22.1 & 0 \\
\hline 7 & 89 & 265 & 1.3 & 0.0 & 22.5 & 0 \\
\hline 8 & 95 & 130 & 0.5 & 0.0 & 22.0 & 0 \\
\hline 9 & 91 & 270 & 1.9 & 0.0 & 21.2 & 0 \\
\hline 10 & 91 & 240 & 0.9 & 0.0 & 21.7 & 0 \\
\hline 11 & 92 & 185 & 0.4 & 0.0 & 24.0 & 0 \\
\hline 12 & 91 & 160 & 0.5 & 0.0 & 23.9 & 0 \\
\hline
\end{tabular}




\begin{tabular}{|c|c|c|c|c|c|c|}
\hline 13 & 96 & 270 & 1.3 & 0.0 & 23.3 & 0 \\
\hline 14 & 95 & 280 & 0.4 & 0.0 & 22.2 & 0 \\
\hline 15 & 94 & 300 & 0.8 & 0.0 & 23.6 & 0 \\
\hline 16 & 93 & 240 & 0.7 & 0.0 & 23.2 & 0 \\
\hline 17 & 95 & 255 & 0.7 & 0.0 & 22.9 & 0 \\
\hline 18 & 92 & 270 & 1.2 & 0.0 & 24.0 & 0 \\
\hline 19 & 94 & 115 & 0.5 & 0.0 & 23.5 & 0 \\
\hline 20 & 94 & 240 & 1.0 & 0.0 & 23.4 & 26 \\
\hline 21 & 96 & 220 & 0.8 & 0.0 & 22.3 & 6820 \\
\hline 22 & 96 & 190 & 0.9 & 0.0 & 22.9 & 130 \\
\hline 23 & 94 & 290 & 0.8 & 0.0 & 24.3 & 0 \\
\hline 24 & 90 & 245 & 0.7 & 0.0 & 24.2 & 940 \\
\hline 25 & 91 & 265 & 0.7 & 0.0 & 24.4 & 0 \\
\hline 26 & 92 & 220 & 0.6 & 0.0 & 23.9 & 0 \\
\hline 27 & 96 & 220 & 0.5 & 0.0 & 23.3 & 3180 \\
\hline 28 & 94 & 245 & 0.7 & 0.0 & 24.1 & 500 \\
\hline 29 & 94 & 050 & 0.7 & 0.0 & 24.1 & 170 \\
\hline 30 & 95 & 240 & 0.7 & 0.0 & 23.8 & 2255 \\
\hline 31 & 96 & 215 & 0.4 & 0.0 & 22.6 & 7760 \\
\hline & & & & & \multicolumn{2}{|c|}{ Sum $=30,697 \mathrm{ml}$} \\
\hline
\end{tabular}

Based on Table 3, on March 2017, due to very hot weather, there are more than a half number of days has no record for volume of water collected with the total of 18 days. Both on 4 th and 20th of March contains the minimum volume of water collected with only $26 \mathrm{ml}$ where the water collection had been evaporated into the atmosphere. The volume of water collected on 31st of March shows the maximum amount of water collection with $7760 \mathrm{ml}$ due to heavy rainfall on that day. The overall volume of water collected on March 2017 is 30,697 $\mathrm{ml}$. 
Table 4.Descriptive statistics on February 2017

\begin{tabular}{cccccc}
\hline & N & Minimum & Maximum & Mean & Std. Deviation \\
\hline No_of_days_February & 28 & 1.00 & 28.00 & 14.5000 & 8.22598 \\
Relative_Humidity & 28 & 90.00 & 97.00 & 94.3571 & 1.87012 \\
Wind_Direction & 28 & 30.00 & 360.00 & 208.2143 & 98.84719 \\
Wind_Speed & 28 & 0.30 & 1.50 & 0.6893 & 0.31072 \\
Rainfall & 28 & 0.00 & 4.10 & 0.1607 & 0.77571 \\
Dry_Bulb_Temperature & 28 & 21.00 & 24.10 & 22.7714 & 0.72052 \\
Volume_of_Water_Collected & 28 & 0.00 & 7300.00 & 641.7143 & 1497.01795 \\
Valid N (listwise) & 28 & & & & \\
\hline
\end{tabular}

Table 5.Descriptive statistics on March 2017

\begin{tabular}{cccccc}
\hline & N & Minimum & Maximum & Mean & Std. Deviation \\
\hline No_of_days_March & 31 & 1.00 & 31.00 & 16.0000 & 9.09212 \\
Relative_Humidity & 31 & 89.00 & 96.00 & 93.8065 & 2.07235 \\
Wind_Direction & 31 & 15.00 & 310.00 & 209.1935 & 79.46799 \\
Wind_Speed & 31 & 0.30 & 1.90 & 0.7290 & 0.33486 \\
Rainfall & 31 & 0.00 & 0.10 & 0.0032 & 0.01796 \\
Dry_Bulb_Temperature & 31 & 21.20 & 24.40 & 23.2258 & 0.85283 \\
Volume_of_Water_Collected & 31 & 0.00 & 7760.00 & 990.2258 & 2113.26694 \\
Valid N (listwise) & 31 & & & & \\
\hline
\end{tabular}

Based on descriptive analysis, there are slightly difference between February and March 2017 found in both Table 4 and 5. Table 4 and 5 show the relationship between the influence of meteorological effects which are relative humidity, wind direction, wind speed, rainfall and dry bulb temperature with the volume of water collected on February and March 2017. As can be seen in Table 4 and 5, volume of water collected on March 2017 has recorded the highest mean with 990.2258 amount of water collected compared to the mean for volume of water collected on February 2017 with only 641.7143. It may occurred because of different total number of days on February and March 2017. On the other hand, it also may occurred due to several meteorological factors such as relative humidity, wind direction, wind speed, rainfall 
and dry bulb temperature that can affect the volume of water collected on both February and March 2017. From the result showed in Table 4 and 5, it can be seen that the mean of relative humidity on February 2017 is 94.3571 which was more humid than on March 2017, 93.8065. Besides, on February 2017, 208.2143 was recorded as the mean of wind direction while 209.1935 was recorded for March 2017. Both table also recorded the mean of wind speed where the mean on March 2017 was faster than on February 2017 with 0.7290 and 0.6893 speed each of them. For rainfall, the mean of rainfall on February 2017 is 0.1607 which was higher compared to 0.0032 mean of rainfall on March 2017. Next, the mean of dry bulb temperature on March 2017 is 23.2258 which was higher than on February 2017 with only 22.7714. Therefore, although the mean of relative humidity and rainfall on February 2017 where higher than on March 2017, it cannot be ensure that the volume of water collected on February 2017 were able to increase higher than March 2017. It is because there are another meteorological factors or elements like wind direction, wind speed and dry bulb temperature that might also contribute to the changes in volume of water collected. This shows that each of the meteorological factors have their own role in maximizing the volume of water collected.

Table 6.Correlations on February 2017

$\begin{array}{cccccc}\text { Relative } & \text { Wind } & \text { Wind } & \text { Rainfall } & \text { Dry } & \text { Volume } \\ \text { Humidity } & \text { Direction } & \text { Speed } & & \text { Bulb } & \text { of Water }\end{array}$

Temperature Collected

\begin{tabular}{|c|c|c|c|c|c|c|c|}
\hline \multirow[t]{3}{*}{$\begin{array}{l}\text { Relative } \\
\text { Humidity }\end{array}$} & $\begin{array}{c}\text { Pearson } \\
\text { Correlation }\end{array}$ & 1 & -0.049 & $-0.382^{*}$ & 0.179 & 0.184 & -0.063 \\
\hline & $\begin{array}{c}\text { Sig. } \\
\text { (2-tailed) }\end{array}$ & & 0.806 & 0.045 & 0.363 & 0.349 & 0.749 \\
\hline & $\mathrm{N}$ & 28 & 28 & 28 & 28 & 28 & 28 \\
\hline \multirow[t]{2}{*}{$\begin{array}{c}\text { Wind } \\
\text { Direction }\end{array}$} & $\begin{array}{c}\text { Pearson } \\
\text { Correlation }\end{array}$ & -0.049 & 1 & 0.219 & 0.191 & -0.227 & 0.002 \\
\hline & $\begin{array}{c}\text { Sig. } \\
\text { (2-tailed) }\end{array}$ & 0.806 & & 0.262 & 0.331 & 0.245 & 0.992 \\
\hline
\end{tabular}




\section{$\begin{array}{ll}\mathrm{N} & 28\end{array}$}

Wind Pearson

Speed Correlation

Sig.

(2-tailed)

$\begin{array}{ll}-0.382^{*} & 0.219\end{array}$

0.045

0.262

$\mathrm{N}$

28

28

28

0.191

$-0.188$

1

0.101

$-0.090$

Correlation

Sig.

(2-tailed)

$\mathrm{N}$

0.363

0.331

0.339

28

28

28

0.610

0.649

28

0.184

$-0.227$

$-0.046$

0.101

1

0.243

Bulb Correlation

Temperature Sig.

(2-tailed)

0.349

0.245

0.816

0.610

0.212

$\mathrm{N}$

28

28

28

28

28

28

Volume Pearson

of Water Correlation

$-0.063$

0.002

0.153

$-0.090$

0.243

1

Collected Sig.

(2-tailed)

0.749

0.992

0.437

0.649

0.212

$\mathrm{N}$ 28 28

28

28

28 28

Table 7. Correlations on March 2017

$\begin{array}{cccccc}\text { Relative } & \text { Wind } & \text { Wind } & \text { Rainfall } & \text { Dry } & \text { Volume } \\ \text { Humidity } & \text { Direction } & \text { Speed } & & \text { Bulb } & \text { of Water }\end{array}$

Temperature Collected

\begin{tabular}{|c|c|c|c|c|c|c|c|}
\hline $\begin{array}{l}\text { Relative } \\
\text { Humidity }\end{array}$ & $\begin{array}{c}\text { Pearson } \\
\text { Correlation }\end{array}$ & 1 & -.352 & $-.390^{*}$ & .196 & -.095 & $.442^{*}$ \\
\hline & $\begin{array}{c}\text { Sig. } \\
\text { (2-tailed) }\end{array}$ & & .052 & .030 & .290 & .611 & .013 \\
\hline
\end{tabular}


$\mathrm{N}$

31

31

31

31

31

31

Wind Pearson

Direction Correlation

Sig. (2-tailed)

$\mathrm{N}$

$-0.352$

1

$0.429^{*} \quad-0.337$

$-0.082$

$-0.214$

0.052

$0.016 \quad 0.064$

0.661

0.249

31

31

31

31

31

31

Wind Pearson

Speed Correlation

$-0.390^{*}$

$0.429^{*}$

$1 \quad-0.016$

$-0.251$

$-0.196$

Sig.

(2-tailed)

$0.030 \quad 0.016$

0.932

0.173

0.292

$\mathrm{N}$

31

31

31

31

31

31

Rainfall Pearson

Correlation

0.196

$-0.337$

$-0.016$

1

0.125

$0.403^{*}$

Sig.

(2-tailed)

$\begin{array}{lll}0.290 & 0.064 & 0.932\end{array}$

$\mathrm{N}$

31

31

31

31

0.503

0.025

Dry Pearson

Bulb Correlation

$\begin{array}{lll}-0.095 & -0.082 & -0.251\end{array}$

0.125

31

31

Temperature Sig.

\begin{tabular}{|c|c|c|c|c|c|c|}
\hline (2-tailed) & 0.611 & 0.661 & 0.173 & 0.503 & & 0.774 \\
\hline $\mathrm{N}$ & 31 & 31 & 31 & 31 & 31 & 31 \\
\hline
\end{tabular}

Volume Pearson

of Water Correlation

$0.442^{*}$

$-0.214$

$-0.196$

$0.403^{*}$

$-0.054$

$-0.054$

Collected Sig.

(2-tailed)

0.013

0.249

$0.292 \quad 0.025$

0.774

$\mathrm{N}$

31

31

31

31

31

31 


\section{CONCLUSION}

This research need to be carried out because it is necessary for people especially in Jeli district, Kelantan to know that atmospheric water harvesting is one of the useful alternatives way to supply sufficient water. Based on the results obtained in this research, it can be concluded that the cylindrical shape of atmospheric water harvester model is capable in withstand any direction of strong wind resistance. This type of model design has been proofed that it could harvest a high volume of water. It means that it has a large potential to be the most suitable design of atmospheric water harvester in Malaysia. The meteorological factors such as wind speed, wind direction, dry bulb temperature, relative humidity and rainfall have gave a big impact in influencing the volume of water collection. The final result shows the volume of water collected on March 2017 is higher compared to the volume of water collected on February 2017. Obviously, with relative humidity above $90 \%$ and heavy rainfall, the conditions are appropriate for harvesting a large amount of atmospheric water such as fog and rain.

\section{ACKNOWLEDGEMENTS}

The authors gratefully acknowledge the Ministry of Higher Education, Malaysia and Universiti Malaysia Kelantan in support of this study through the Short-Term Research Grant Scheme (SGJP) R/SGJP/A08.00/00425A/001/2016/000347 .

\section{REFERENCES}

[1] Andrews HG, Eccles EA, Schofield WC, Badyal JP. Three-dimensional hierarchical structures for fog harvesting. Langmuir, 2011, 27(7):3798-3802

[2] Aroka N. Rainwater Harvesting in Rural Kenya: Reliability in a variable and changing climate.Master thesis, Stockholm: Stockholm University, 2010

[3] Davtalab R, Salamat A, Oji R. Water harvesting from fog and air humidity in the warm and coastal regions in the south of Iran. Irrigation and Drainage, 2013, 62(3):281-288

[4] Department of Statistics Malaysia (DOSM).Malaysia @ a Glance-Kelantan. Putrajaya: DOSM, 2017 
[5] MolokáčM, VégsöováO. Gemstones in geotourism. GeoJournal of Tourism and Geosites, $2015,15(1): 7-13$

[6] Esfandiarnejad A, Ahangar R, Kamalian UR, Sangchouli T. Feasibility studies for water harvesting from fog and atmospheric moisture in Hormozgan coastal zone (south of Iran). In5th International Conference on Fog, Fog Collection and Dew, 2010, pp. 25-30

[7] Adriansyah D, Busu I, Eva H, Muqtada M. Geoheritage as the basis of geotourism development: A case study in Jeli district, Kelantan, Malaysia. GeoJournal of Tourism and Geosites, 2015, 15:25-43

[8] Ibrahim I A. Investigation of rainwater harvesting techniques in Yatta District, Kenya. Master thesis, Nairobi: Jomo Kenyatta University of Agriculture And Technology, 2012

[9] Ismail M G, Rahman H A. Public Involvement on Environment Issues in Kota Bharu and Jeli District, Kelantan. Journal of Social Sciences, 2011, 7(2):175-181

[10] Karkee MB. Harvesting of atmospheric water: A promising low-cost technology. In 9th International Water Technology Conference 2005, pp. 3-14

[11] Qadir M, Sharma BR, Bruggeman A, Choukr-Allah R, Karajeh F. Non-conventional water resources and opportunities for water augmentation to achieve food security in water scarce countries. Agricultural Water Management, 2007, 87(1):2-22

[12] United Nations (UN).In focus: We're finally at the end of the UN decade for water 2005-2015-It is time to say good-bye. International Decade for Action 'Water for Life' 2005-2015: UN-Water Decade Programme on Advocacy and Communication (UNW-DPAC). New York: United Nations Department of Economic and Social Affairs, 2017

[13] Wong I, Teo GH, Neto C, Thickett SC. Micropatterned surfaces for atmospheric water condensation via controlled radical polymerization and thin film dewetting. ACS Applied Materials and Interfaces, 2015, 7(38):21562-21570

\section{How to cite this article:}

Zol N A, Isa N H M, Awang N R, Ahmad M I, Rasat M S M, Amin M F M, Rizman Z I. Atmospheric water harvester: meteorological effect on water collection. J. Fundam. Appl. Sci., $2017,9(3 S), 844-857$ 